\title{
ECC Refrigerator: Investigate Potential Energy Savings and Likelihood of Success if an ECC is Used Instead of a Typical Vapor Compressor
}

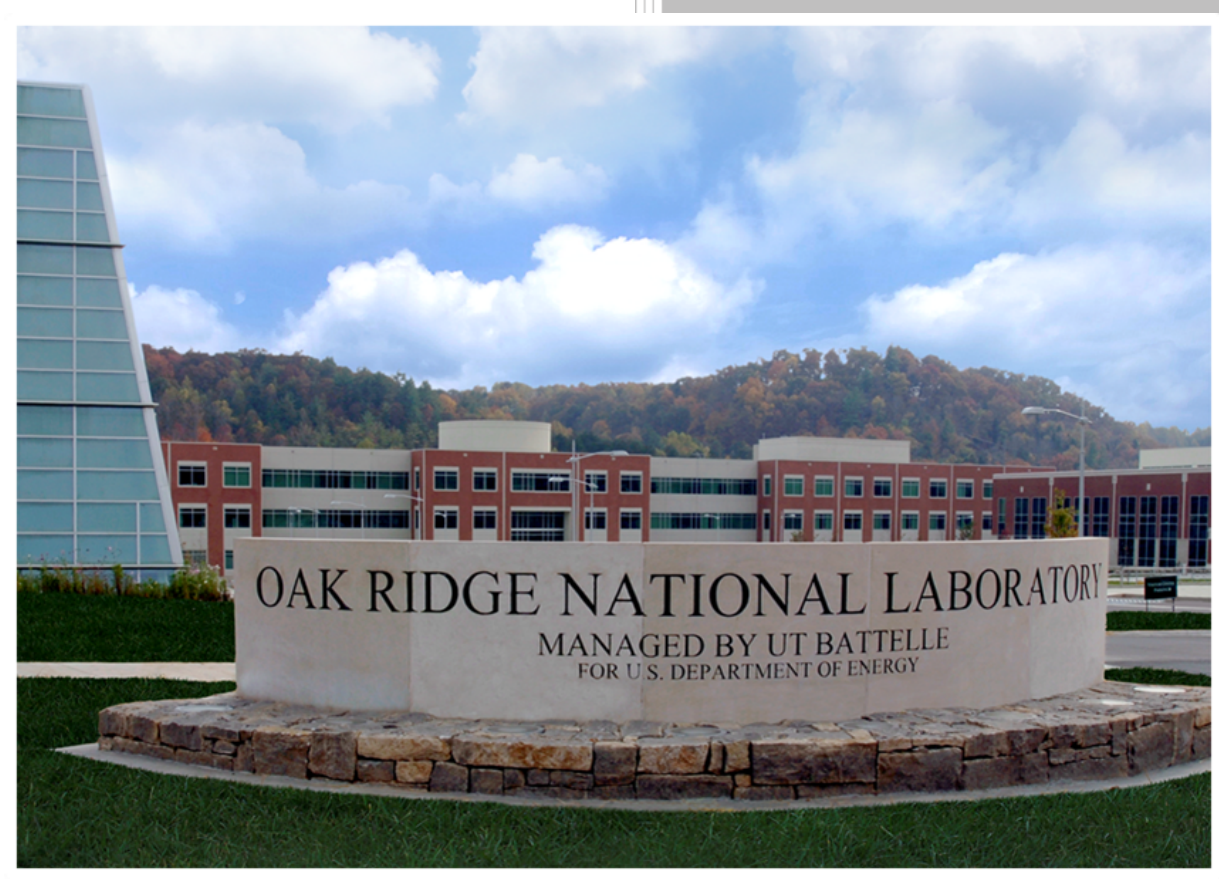

Bo Shen

Ayyoub Momen

Approved for public release. Distribution is unlimited. 


\title{
DOCUMENT AVAILABILITY
}

Reports produced after January 1, 1996, are generally available free via US Department of Energy (DOE) SciTech Connect.

Website http://www.osti.gov/scitech/

Reports produced before January 1, 1996, may be purchased by members of the public from the following source:

\author{
National Technical Information Service \\ 5285 Port Royal Road \\ Springfield, VA 22161 \\ Telephone 703-605-6000 (1-800-553-6847) \\ TDD 703-487-4639 \\ Fax 703-605-6900 \\ E-mail info@ntis.gov \\ Website http://www.ntis.gov/help/ordermethods.aspx
}

Reports are available to DOE employees, DOE contractors, Energy Technology Data Exchange representatives, and International Nuclear Information System representatives from the following source:

Office of Scientific and Technical Information

PO Box 62

Oak Ridge, TN 37831

Telephone 865-576-8401

Fax 865-576-5728

E-mail reports@osti.gov

Website http://www.osti.gov/contact.html

This report was prepared as an account of work sponsored by an agency of the United States Government. Neither the United States Government nor any agency thereof, nor any of their employees, makes any warranty, express or implied, or assumes any legal liability or responsibility for the accuracy, completeness, or usefulness of any information, apparatus, product, or process disclosed, or represents that its use would not infringe privately owned rights. Reference herein to any specific commercial product, process, or service by trade name, trademark, manufacturer, or otherwise, does not necessarily constitute or imply its endorsement, recommendation, or favoring by the United States Government or any agency thereof. The views and opinions of authors expressed herein do not necessarily state or reflect those of the United States Government or any agency thereof. 
ORNL/TM-2018/528

\title{
Building Technologies Research and Integration Center
}

BTO Project 3.2.2.26

FY17 $2^{\text {nd }}$ Milestone Report

Investigate Potential Energy Savings and Likelihood of Success if an ECC is Used Instead of a Typical Vapor Compressor

\author{
Authors \\ Bo Shen, Ayyoub Momen
}

Date: 10/31/2017

\author{
Prepared by \\ OAK RIDGE NATIONAL LABORATORY \\ Oak Ridge, TN 37831-6283 \\ managed by \\ UT-BATTELLE, LLC \\ for the \\ US DEPARTMENT OF ENERGY \\ under contract DE-AC05-00OR22725
}




\section{Investigate Potential Energy Savings and Likelihood of Success if an ECC is Used Instead of a Typical Vapor Compressor (Go/No Go)}

\section{Executive Summary}

This report estimates energy saving potential of a refrigerator using an electrochemical compressor (ECC) and metal hydride heat exchangers, versus a baseline refrigerator using a single-speed reciprocating compressor. The ECC technology has is more efficient at high pressure ratio and has better part-load performance. In addition, metal hydrides are solid refrigerants suitable for extensive applications, having larger formation heat. It has the potential to achieve energy saving over $20 \%$ than the baseline refrigerator, after we break the technical barriers on the path. Based on evaluation of the project against the must meet criteria, it meets the requirements for a "go" decision.

\section{Baseline System}

Vapor compression systems have drastic performance degradation when increasing the pressure ratio, because of the losses caused by re-expansion of residue volume, reduced motor efficiency, etc. The selected baseline refrigerator uses a single-speed, reciprocating-piston compressor. We converted the measured compressor mass flow rate and power consumption to isentropic and volumetric efficiencies, as a function of the evaporating temperature, Te, and condensing temperature, Tc, as shown in Figures 1 and 2. These two figures represent typical isentropic and volumetric efficiency reductions with increasing the pressure ratio, i.e. Pressure at Tc/Pressure at Te. Large pressure ratios of refrigerator/freezer applications cause low system cooling efficiency and reduced refrigerating capacity. In addition, the single-speed refrigerator has cyclic loss due to turning the compressor on/off to meet the temperature setting point. The average $\mathrm{COP}$ of the baseline refrigerator was given as $\mathbf{1 . 3 3}$.

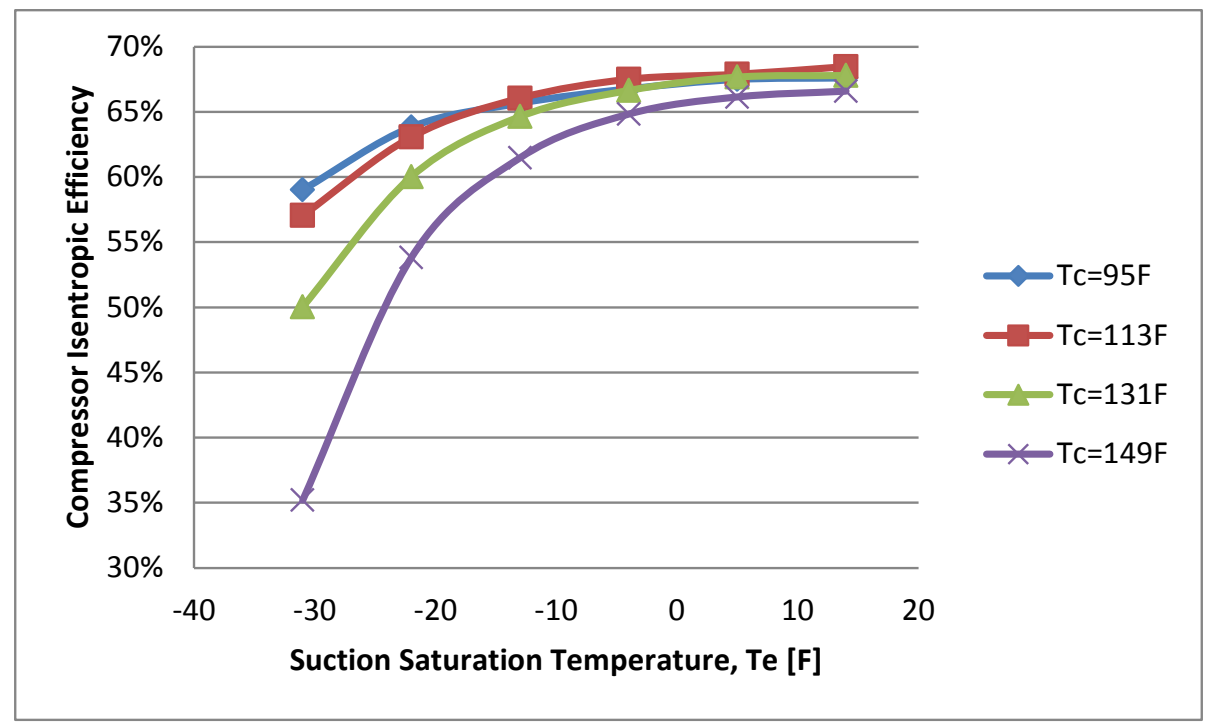

Figure 1: Compressor Isentropic Efficiency Plot 


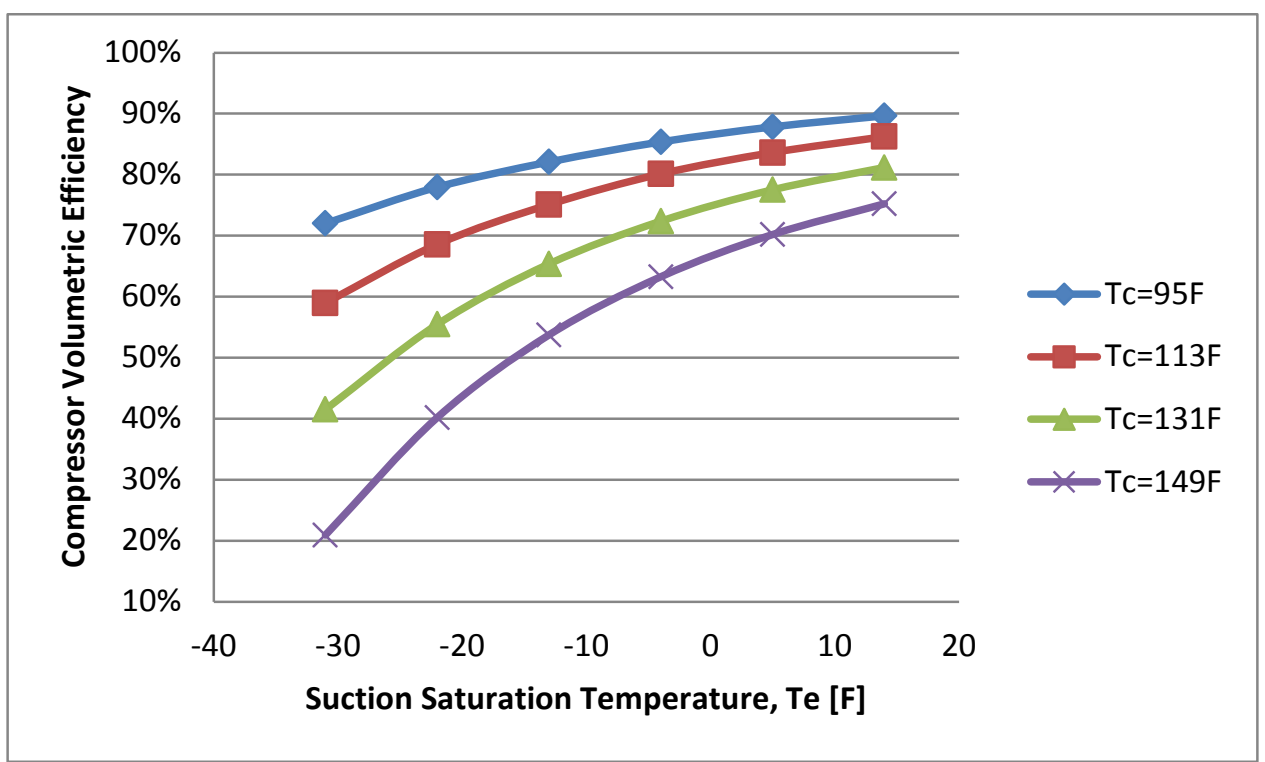

Figure 2: Compressor Volumetric Efficiency Plot

\section{Energy Saving Potentials of Electrochemical Compression using Metal Hydride Heat Exchangers}

\section{An electrochemical compressor is more efficient at high pressure ratio}

Electrochemical compressors (ECC) use membrane. The electrical voltage across a membrane consists of three parts,

$$
U=U_{\text {Nernst }}+U_{o h m}+U_{a c}
$$

Where $U_{\text {Nernst }}$ is Nernst potential, i.e. the actual force driving the hydrogen flow. $U_{a c}$ is caused by the anode and cathode polarization, which is usually negligible for an ECC compressor using membranes. $U_{\text {ohm }}$ is caused by the electrical resistance in the membrane, which is a loss factor and converts electrical energy to heat.

$$
U_{\text {ohm }}=I \times R_{i}
$$

Where $R_{i}$ is the internal electrical resistance of the membrane.

$$
U_{\text {Nernst }}=\frac{R \times T_{E C}}{2 F} \ln \left(P_{\text {dis }} / P_{\text {suc }}\right)
$$

Where $R$ is the gas constant, $T_{E C}$ is the ECC compressor's process temperature $[\mathrm{K}] . P_{\text {dis }}[\mathrm{pa}]$ is the compressor's discharge temperature and $P_{\text {suc }}[\mathrm{pa}]$ is the suction pressure.

Thus, the electrochemical efficiency of the compressor is defined as Equation (4).

$$
\eta_{E C}=U_{\text {Nernst }} /\left(U_{\text {Nernst }}+U_{\text {ohm }}\right)
$$

It can be seen that the electrochemical compression has advantages for the refrigerator application with high pressure ratios. High pressure ratios lead to larger $U_{\text {Nernst }} / U_{\text {ohm }}$ at the same electric current (hydrogen flow rate). As reported by [1] and illustrated in the table below, a state-of-art electrochemical compressor reached an isentropic efficiency of $75 \%$ having a pressure ratio of 293 . 
TABLE 1. Progress Made Towards Meeting Technical Targets for Small

Compressors for Fueling Sites [1]

\begin{tabular}{|c|c|c|c|}
\hline Characteristic & Units & DOE 2015 Target & FCE Status \\
\hline Reliability & - & Improved & $20,000 \mathrm{~h}^{\S 8}$ \\
\hline $\begin{array}{l}\text { Compressor Efficiency } \\
\text { (Isentropic) }\end{array}$ & $\%$ & $73 \%$ & $75 \%^{5 \#}$ \\
\hline $\begin{array}{l}\text { Losses (\% of } \mathrm{H}_{2} \\
\text { throughput) }\end{array}$ & $\%$ & 0.5 & $1^{f_{\#}^{\#}}$ \\
\hline Uninstalled Capital Cost & $\$$ & 400,000 & $\begin{array}{l}\text { 300,000 Projected } \\
\text { for EHC Stack }\end{array}$ \\
\hline $\begin{array}{l}\text { Outlet Pressure } \\
\text { Capability }\end{array}$ & bar & 860 & Up to $880^{* \Lambda}$ \\
\hline Contamination & - & Varies by Design & None \\
\hline
\end{tabular}

${ }^{8}$ For compression from 3 to 208 bar; ${ }^{\wedge} 3$ bar inlet pressure; ${ }^{8} 0.1 \mathrm{~kg} \mathrm{H} / \mathrm{d}$;

${ }^{*} 0.3 \mathrm{~kg} \mathrm{H}_{2} / \mathrm{d} ;{ }^{*}<0.01 \mathrm{~kg} \mathrm{H}_{2} / \mathrm{d}$

\section{Electrochemical compressors have better part-load performance.}

Hydrogen flow rate of an electrochemical compressor can be varied by adjusting the DC power input, i.e. electric current. And it doesn't have on/off cyclic loss like a mechanical compressor. Therefore, it has the advantage of a variable-speed compressor, and will lead to superior part load performance in a refrigerator system.

\section{Metal hydride alloys are solid refrigerants}

Metal hydride (MH) alloys have great potential to replace refrigerants in vapor compression systems. Metal hydrides are widely used to store hydrogen in automobile and power industries. As shown in the figure below, some metals can be bonded with hydrogen and form metal hydrides. With increasing the hydrogen concentration, the material bond goes through the $\alpha$ phase, similar to the subcooled state of a refrigerant; in the $\alpha+\beta$ phase, the absorption/desorption temperature at a given plateau pressure doesn't change, similar to the two-phase state of a pure refrigerant; in the $\beta$ phase, the hydride's temperature increases with the concentration, like the superheat state of a refrigerant. The whole process is reversible from absorption to desorption. Major energy transfer of hydrogen absorption/desorption occurs in the $\alpha+\beta$ phase. The energy change is defined as formation heat absorbed per mole of hydrogen, $\left[\mathrm{kJ} / \mathrm{mole} \mathrm{H}_{2}\right]$. 


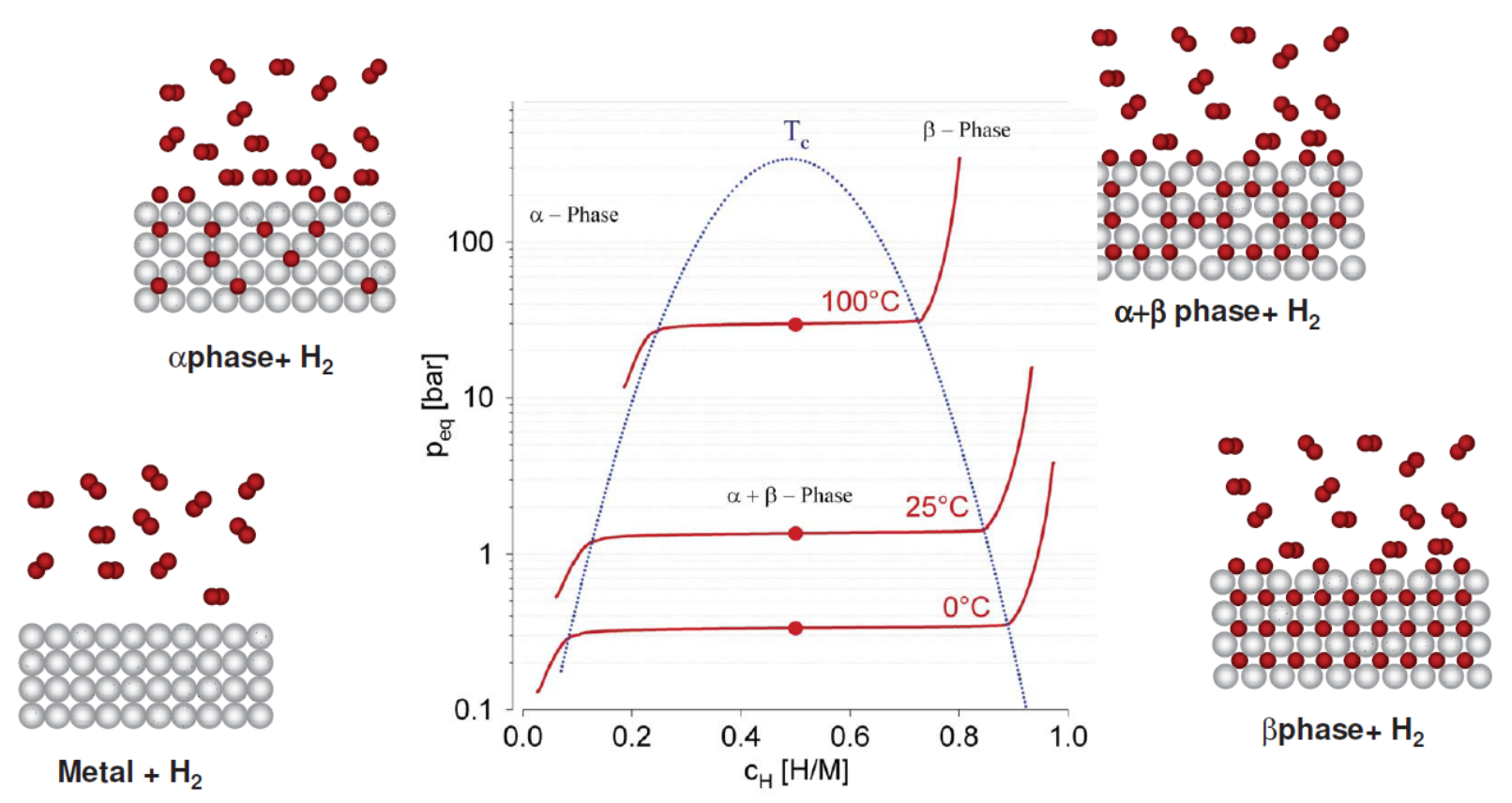

Figure 3: Mechanism of Metal Hydride Absorbing (Desorbing) Hydrogen

Various MH alloys are suitable for hydrogen compression system, as Table 2 summarized by [2]. It shall be noted that formation heat $(-\Delta \mathrm{H} 0)$ ranges from 20 to $50 \mathrm{~kJ} / \mathrm{mole}_{2}$. Formation heat is equivalent to latent evaporation heat of a refrigerant. R-134a, a typical refrigerant used for refrigerators, has the latent evaporation heat of $22.7 \mathrm{~kJ} /$ mole at $-30^{\circ} \mathrm{F}$. It can be seen, most of the $\mathrm{MH}$ alloys have higher formation heat than R-134a. 
Table 2: Equilibrium characteristics of MH Alloys, cited from [2]

Equilibrium characteristics of the interaction of hydride-forming alloys suitable for $\mathrm{H}_{2}$ compression with $\mathrm{H}_{2}$ gas in plateau region. The data are sorted in the ascending order for desorption plateau pressure at $T=25^{\circ} \mathrm{C}\left(\mathrm{P}_{\mathrm{D}}\right)$. The plateau pressures are calculated using Equation $(2)$; the lower $\left(P_{L}\right)$ and higher $\left(P_{H}\right)$ values correspond to the lower $\left(T_{L}\right)$ and $h i g h e r\left(T_{H}\right)$ temperatures, respectively, as reported in the original works.

\begin{tabular}{|c|c|c|c|c|c|c|c|c|c|}
\hline \multirow[t]{2}{*}{$\#^{\mathrm{a}}$} & \multirow[t]{2}{*}{ Alloy } & \multirow{2}{*}{$\left.\left.\begin{array}{c}-\Delta S^{0} \\
\mathbb{J} /(\operatorname{mol~H} \\
2\end{array}\right)\right]$} & \multirow{2}{*}{$\begin{array}{c}-\Delta H^{0} \\
{\left[\mathrm{~kJ} / \mathrm{mol} \mathrm{H} \mathrm{H}_{2}\right]}\end{array}$} & \multicolumn{2}{|c|}{ Temperature range $\left[{ }^{\circ} \mathrm{C}\right]$} & \multicolumn{3}{|c|}{ Pressure [atm] } & \multirow[t]{2}{*}{ Ref. } \\
\hline & & & & $\mathrm{T}_{\mathrm{L}}$ & $\mathrm{T}_{\mathrm{H}}$ & $P_{0}$ & $P_{L}$ & $P_{\mathrm{H}}$ & \\
\hline 1 (A) & $\mathrm{V}_{75} \mathrm{Ti}_{175} \mathrm{Zr}_{75}$ & 145.1 & 52.98 & 30 & 120 & 0.02 & 0.03 & 3.47 & [15] \\
\hline 2 (B) & $\mathrm{MmNi}_{4.8 \mathrm{Ala}_{2}}$ & 111.3 & 37.20 & 50 & 150 & 0.02 & 0.63 & 16.66 & {$[16]^{\mathrm{b}}$} \\
\hline 3 (B) & $\mathrm{LaNi}_{4.7} \mathrm{Sn}_{03}$ & 112.6 & 36.51 & 25 & 80 & 0.31 & 0.31 & 3.03 & [17] \\
\hline 4 (A) & $\mathrm{V}_{75} \mathrm{Ti}_{10} \mathrm{Zr}_{75} \mathrm{Cr}_{75}$ & 132.3 & 42.23 & 30 & 120 & 0.32 & 0.43 & 19.90 & [15] \\
\hline \multirow[t]{2}{*}{5 (B) } & $\mathrm{LaNi}_{4.8} \mathrm{Sn}_{0.2}$ & 104.3 & 32.83 & 20 & 90 & 0.50 & 0.40 & 5.32 & {$[18]^{\mathrm{b}}$} \\
\hline & & 105.0 & 32.80 & 0 & 240 & 0.55 & 0.16 & 139.9 & [19] \\
\hline 6 (B) & $\mathrm{Mm}_{0.5} \mathrm{La}_{0.5} \mathrm{Ni}_{4.7} \mathrm{Sn}_{0.3}$ & 111.2 & 33.80 & 25 & 80 & 0.77 & 0.77 & 6.44 & [17] \\
\hline 7 (B) & $\mathrm{LaNi}_{4} \mathrm{Al}_{02}$ & 101.6 & 30.40 & 50 & 150 & 0.96 & 2.47 & 35.84 & {$[16]^{\mathrm{b}}$} \\
\hline 8 (B) & $\mathrm{LaNi}_{5}$ & 110.0 & 31.80 & 25 & 200 & 1.49 & 1.49 & 171.9 & {$[20,21]^{\mathrm{b}}$} \\
\hline 9 (B) & $\mathrm{MmNi}_{4.7} \mathrm{Fe}_{0.3}$ & 87.4 & 25.00 & 20 & 102 & 1.53 & 1.29 & 12.14 & {$[22]^{\mathrm{b}}$} \\
\hline $10(\mathrm{~A})$ & $\mathrm{V}_{0.85} \mathrm{Ti}_{0.1} \mathrm{Fe}_{0.05}$ & 148.0 & 42.90 & -20 & 100 & 1.64 & 0.08 & 53.14 & {$[20,23]^{\mathrm{b}}$} \\
\hline $11(\mathrm{C})$ & $\mathrm{TiFe}_{0.9} \mathrm{Mn}_{0.1}$ & 107.7 & 29.70 & 0 & 100 & 2.64 & 0.88 & 29.39 & {$[20,24]^{b}$} \\
\hline $12(\mathrm{~B})$ & $\mathrm{La}_{0.85} \mathrm{Ce}_{0.15} \mathrm{Ni}_{5}$ & 91.28 & 24.30 & 10 & 110 & 3.24 & 1.93 & 28.50 & $b, c$ \\
\hline $13(\mathrm{~B})$ & $\mathrm{MmNi}_{4.7} \mathrm{Al}_{0.3}$ & 107.8 & 28.88 & 20 & 90 & 3.73 & 3.05 & 29.98 & [18] \\
\hline $14(\mathrm{~A})$ & $V_{92.5} Z_{r_{7.5}}$ & 147.0 & 40.32 & 30 & 60 & 4.11 & 5.38 & 22.71 & [15] \\
\hline $15(\mathrm{~B})$ & $\mathrm{La}_{0.2} \mathrm{Y}_{0.8} \mathrm{Ni}_{4.6} \mathrm{Mn}_{\mathrm{Q} .4}$ & 105.3 & 27.10 & 20 & 90 & 5.62 & 4.67 & 39.78 & [25] \\
\hline 16 (D) & $\mathrm{Zr}_{0.7} \mathrm{Ti}_{0.3} \mathrm{Mn}_{2}{ }^{\mathrm{d}}$ & 85.0 & 21.00 & 30 & 150 & 5.77 & 6.63 & 70.41 & {$[26]^{\mathrm{b}}$} \\
\hline 17 (D) & $\mathrm{Ti}_{0.9} \mathrm{Zr}_{0.1} \mathrm{Mn}_{1.4} \mathrm{Cr}_{0.35} \mathrm{~V}_{0.2} \mathrm{Fe}_{0.05}{ }^{\circ}$ & 106.9 & 25.89 & 25 & 100 & 11.17 & 11.17 & 91.14 & {$[27]$} \\
\hline $18(\mathrm{~B})$ & $\mathrm{MmNi}_{4.15} \mathrm{Fe}_{0.85}$ & 105.4 & 25.00 & 25 & 200 & 11.36 & 11.36 & 502.8 & {$[20,24]^{\mathrm{b}}$} \\
\hline $19(\mathrm{~B})$ & $\mathrm{La}_{0.4} \mathrm{Ce}_{0.4} \mathrm{Ca}_{0.2} \mathrm{Ni}_{5}$ & 115.3 & 28.20 & 15 & 100 & 12.08 & 8.14 & 118.9 & {$[28]$} \\
\hline 20 (D) & $\mathrm{Ti}_{0.8} \mathrm{Zr}_{0.2} \mathrm{CrMn}$ & 108.6 & 24.60 & -20 & 50 & 23.06 & 3.95 & 49.69 & {$[20]^{b}$} \\
\hline $21(B)$ & $\mathrm{Mm}_{1-x} \mathrm{Ca}_{x} \mathrm{Ni}_{5-y} \mathrm{Al}_{y}{ }^{e}$ & 103.0 & 22.85 & 5 & 90 & 23.82 & 12.28 & 124.0 & [29] \\
\hline $22(\mathrm{~B})$ & $\mathrm{Ca}_{0.2} \mathrm{Mm}_{0.8} \mathrm{Ni}_{5}$ & 109.5 & 24.50 & 0 & 100 & 26.75 & 10.83 & 195.0 & {$[20,24]^{\mathrm{b}}$} \\
\hline 23 (D) & $\mathrm{Zr}_{0.8} \mathrm{Ti}_{0.2} \mathrm{FeNi}_{0.8} \mathrm{~V}_{0.2}$ & 118.3 & 26.80 & 20 & 90 & 30.49 & 25.35 & 211.1 & {$[30]^{\mathrm{b}}$} \\
\hline $24(\mathrm{D})$ & $\mathrm{Ti}_{0.77} \mathrm{Zr}_{0.3} \mathrm{Cr}_{0.85} \mathrm{Fe}_{0.7} \mathrm{Mn}_{0.25} \mathrm{Ni}_{0.2} \mathrm{Cu}_{0.03}$ & 93.66 & 19.26 & 20 & 110 & 32.98 & 28.88 & 184.8 & c \\
\hline 25 (D) & $\mathrm{TiCr}_{19} \mathrm{Mo}_{0.01}$ & 113.0 & 24.80 & -50 & 90 & 36.11 & 1.25 & 216.4 & [30] \\
\hline 26 (D) & $\mathrm{TiCr}_{19}$ & 122.0 & 26.19 & -100 & 30 & 60.77 & 0.03 & 72.34 & {$[31]^{\mathrm{b}}$} \\
\hline 27 (D) & $\mathrm{ZrFe}_{1.8} \mathrm{Cr}_{02}$ & 109.0 & 22.30 & 20 & 90 & 61.19 & 52.49 & 306.2 & [30] \\
\hline 28 (D) & $\left(\mathrm{Ti}_{0.97} \mathrm{Zr} \mathrm{r}_{0.03}\right)_{1.1} \mathrm{Cr}_{1.6} \mathrm{Mn}_{0.4}$ & 115.0 & 23.40 & 10 & 99 & 80.80 & 49.00 & 527.9 & [32] \\
\hline 29 (D) & $\mathrm{TiCr}_{15} \mathrm{Mn}_{0.25} \mathrm{Fe}_{0.25}{ }^{\circ}$ & 101.6 & 19.32 & -10 & 165 & 83.61 & 29.65 & 1009 & [27] \\
\hline 30 (D) & $\mathrm{TiCr}_{15} \mathrm{Mn}_{\mathrm{O}_{2}} \mathrm{Fe}_{03}{ }^{\mathrm{e}}$ & 101.0 & 18.32 & -10 & 148 & 116.4 & 43.57 & 1008 & {$[27]$} \\
\hline 31 (D) & TiCrMn & 106.0 & 19.60 & -60 & 100 & 126.8 & 5.42 & 621.2 & {$[34]^{\mathrm{b}}$} \\
\hline 32 (D) & $\mathrm{ZrFe}_{1.8} \mathrm{Ni}_{0.2}$ & 119.7 & 21.50 & 20 & 90 & 306.0 & 264.0 & 1445 & [30] \\
\hline 33 (D) & Ti ${ }_{0.86} \mathrm{Mo}_{0.14} \mathrm{Cr}_{1.9}$ & 117.0 & 17.20 & -50 & 90 & 1253 & 121.7 & 4340 & [30] \\
\hline
\end{tabular}

For the prototype ECC compressor, provided by Xergy Inc., the figure below compares the isentropic efficiency curves with using a single ECC compressor and put two in parallel (reduced ohm loss). Using two ECC compressors in parallel can increase the isentropic efficiency to $67 \%$ at the 0.7 A current. 


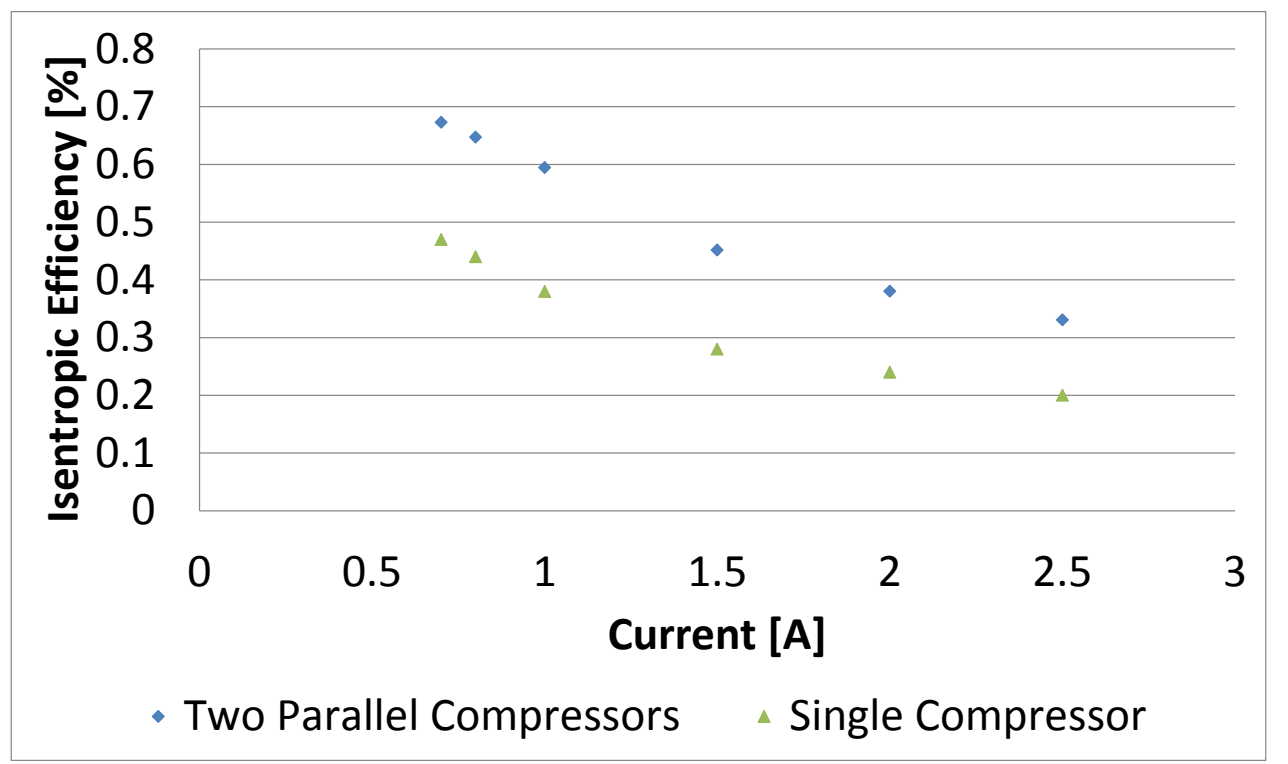

Figure 4: Isentropic Efficiency Curves with using a single and two parallel ECC compressors.

Figure 4 presents the max theoretical COPs using one or two parallel prototype ECC compressors (formation heat/ECC power consumption absorbing one mole $\mathrm{H}_{2}$ ), assuming the formation heat of 20 $\mathrm{kJ} /$ mole (Low) $\mathrm{H}_{2}$ and $40 \mathrm{~kJ} / \mathrm{mole} \mathrm{H}_{2}$ (High), respectively. It can be seen, if use a species of $\mathrm{MH}$ alloy having the high formation heat and operate the ECC compressor(s) at small current densities, the ECC refrigerator can achieve COPs at least $20 \%$ higher than the baseline refrigerator having an average COP of 1.33 .

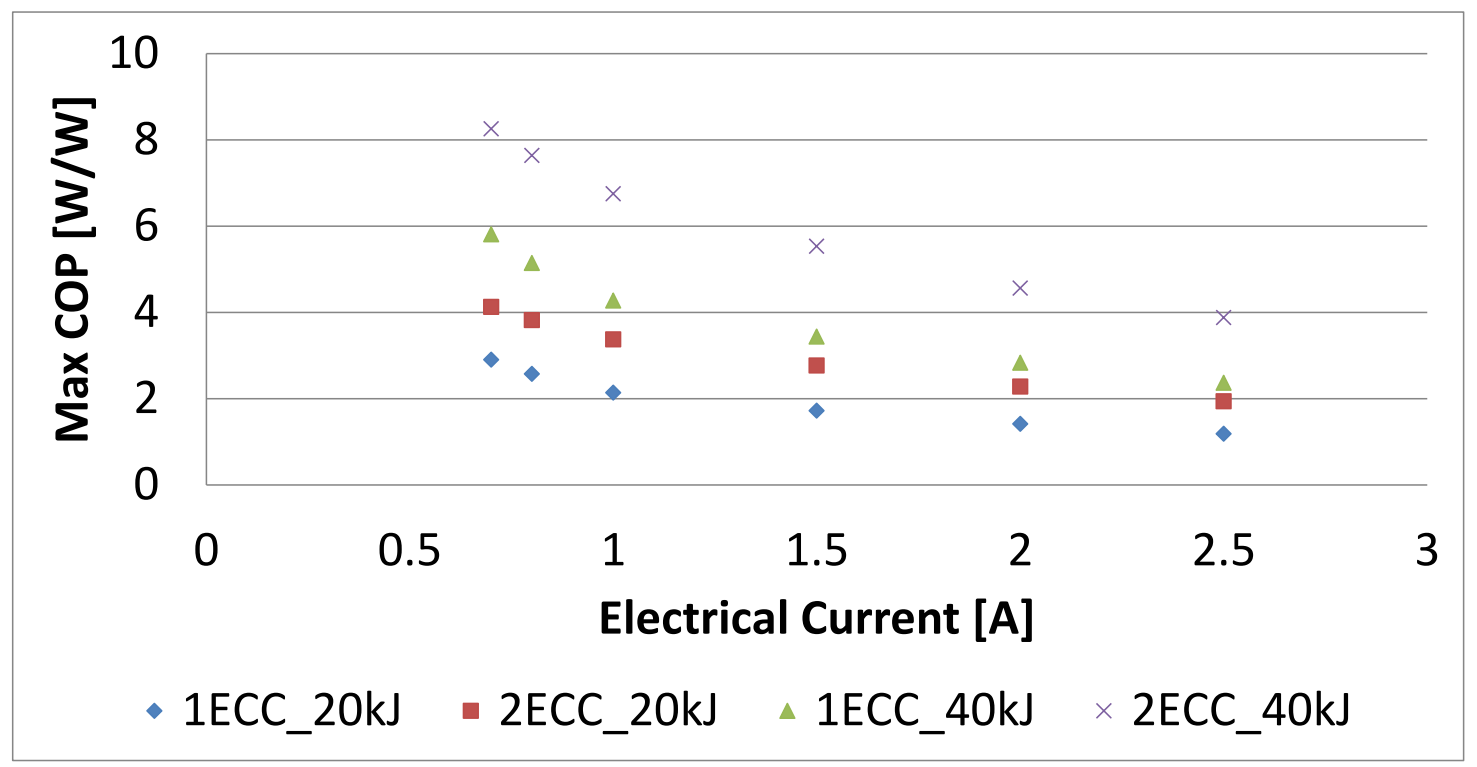

Figure 5: Max COPs of ECC refrigerator using one or two ECC compressors, with the formation heat of $20 \mathrm{~kJ} / \mathrm{mole}_{2}$ and $40 \mathrm{~kJ} / \mathrm{mole}_{2}$.

\section{References}

[1] DOE Hydrogen and Fuel Cells Program, 2015, FY 2015 Annual Progress Report, https://www.hydrogen.energy.gov/pdfs/progress15/iii_10_lipp_2015.pdf 
[2] M.V. Lototskyy, V.A. Yartys, B.G. Pollet, R.C. Bowman, Metal hydride hydrogen compressors: A review, In International Journal of Hydrogen Energy, Volume 39, Issue 11, 2014, Pages 5818-5851, ISSN 0360-3199, https://doi.org/10.1016/j.ijhydene.2014.01.158. 